\title{
Study of Genetic Variability and Heritability in Sugarcane (Saccharum spp. Complex)
}

\author{
P.P. Patil ${ }^{*}$ and D.U. Patel \\ Department of Genetics and Plant Breeding, N.M. College of Agriculture, \\ Navsari Agricultural University, Navsari-396 450, Gujarat, India \\ *Corresponding author
}

\section{A B S T R A C T}

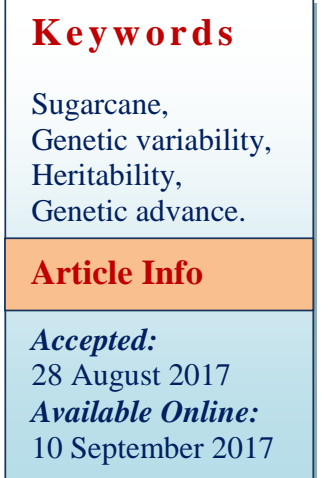

\section{Introduction}

Sugarcane (Saccharum spp. hybrids) is an important agro industrial crop and knowledge of heritability of agronomic traits is important in breeding program worldwide. The genetic variability present in the sugarcane cultivars, cultivated by the producers, has hybrid origin, generally. The Saccharum officinarum has been contributing for genetic variability in sugarcane more than $S$. spontaneum, $S$. sinense and $S$. barberi. In the genetic breeding program of sugarcane the main goal is to obtain new cultivars with more productivity and best industrial characteristics. Nowadays the plant breeding has been based on a common genetic base obtained by the pioneer ones from the beginning of the century, through inter crosses and retro crosses of
S. officinarum. Sugarcane varieties in commercial cultivation are complex polyploid. The heterozygous and polyploidy natures of this crop have resulted in generation of greater genetic variability. The information on the nature and the magnitude of variability present in the genetic material is of prime importance for a breeder to initiate any effective selection program. Also genetic advance are very essential to improve any trait of sugarcane because this would help in knowing whether or not the desired objective can be achieved from the material (Tyagi and Singh, 1998).

Hence, the objective of present study was carried out to describe the nature and extent 
of genetic variability, heritability and genetic advance between yield and related traits for the studied genotypes.

\section{Materials and Methods}

The experimental material consisted of 30 genotypes of sugarcane obtained from the germplasm maintained at Main Sugarcane Research Station, Navsari Agricultural University, Navsari and grown during 201011 in Randomized Block Design (RBD) with three replications. The gross plot size for each genotype was consisted of five rows each of six meter length with row to row spacing of $90 \mathrm{~cm}$ and the net plot was consisted of middle 3 rows each of 5 meter length with row to row spacing of $90 \mathrm{~cm}$ (excluding $0.5 \mathrm{~m}$ ring line at both ends of the plot). The two budded setts of sugarcane were planted in rows keeping 12 buds per meter row length. The crop was raised under irrigated conditions following all the recommended package of practices and $50 \%$ recommended dose of NPK fertilizer i.e. $125 \mathrm{~kg} \mathrm{~N}+62.5 \mathrm{~kg}$ $\mathrm{P}_{2} \mathrm{O}_{5}+62.5 \mathrm{~kg} \mathrm{~K} 2 \mathrm{O}$ per ha + Acetobacter @ 2.5 lit/ha. The observations were recorded on yield components and quality traits viz., germination $\%$ at 45 days, tillers at 120 days (000/ha), shoots at 240 days (000/ha), stalk height at 360 days $(\mathrm{cm})$, stalk diameter at 360 days $(\mathrm{cm})$, internodes/stalk at 360 days, stalk weight at 360 days $(\mathrm{kg})$, number of millable canes/ha (NMC) at 360 days (000/ha), cane yield at harvest ( $\mathrm{t} / \mathrm{ha}$ ), juice brix $\%$ at 360 days, sucrose $\%$ juice at 360 days, juice purity $\%$ at 360 days, CCS \% at 360 days, Fibre \% cane at 360 days, pol \% cane at 360 days and sugar yield at 360 days (t/ha). The analysis of variance was carried out following the procedure of Panse and Sukhatme (1978). The genotypic and phenotypic variations, phenotypic and genotypic coefficient of variability, heritability in broad sense and genetic advance as per cent of mean were determined as per the standard procedure.

\section{Results and Discussion}

The analysis of variance indicating the genotypic differences were highly significant for all the characters indicating considerable amount of genetic variability among the genotypes tested in the present study (Table 1). This indicated an ample scope of exploitation of the characters under study. Similar results were reported by Kumar et al., (2004), Patel et al., (2006), Rahman et al., (2008), Rahman and Bhuiyan (2009), Anbanandan and Saravanan (2010) and Tyagi et al., (2011).

The wide range of genotypic and phenotypic variation was observed for tillers at 120 days (510.41 and 627.75) followed by stalk height at 360 days (395.06 and 725.15) and shoots at 240 days (382.97 and 532.63). The low estimates of $\sigma^{2} g$ and $\sigma^{2} p$ were exhibited by internodes per stalk at 360 days (3.16 and 4.82 ), juice purity $\%$ (1.74 and 3.62), CCS t/ha (1.62 and 2.94) and rest of the traits. Similar findings were reported by Hapase and Hapase (1990) and Verma et al., (1999) and Khan et al., (1991) found variability of higher magnitude for number of shoots per plot, NMC and cane yield. Also Rahman et al., (2008), Kumar et al., (2010), Anbanandan and Saravanan (2010) and Pawar et al., (2011) found similar results for most of the cane yield and its contributing traits.

The characters, viz., NMC at harvest (80.05 and 112.76), cane yield (64.44 and 109.79) and germination \% at 45 days (52.66 and 69.98) had moderate values of $\sigma^{2} g$ and $\sigma^{2} p$ variance. Such type of results was reported by Doule and Balasundaram (1997), Kadian et al., (1997), Verma et al., (1999) and Rahman and Bhuiyan (2009). A perusal of the estimates of environmental component of variance in relation to their genotypic counterpart revealed that the estimates of $\sigma^{2} \mathrm{~g}$ were higher than $\sigma^{2}$ e for most of the 
characters. The higher magnitude of genotypic variance suggested little influence of environments in the expression of genetic variability.

The estimates of genotypic and phenotypic coefficient of variation were high for shoots at 240 days (13.68 and 16.14) followed by germination $\%$ at 45 days (12.90 and 14.87) and tillers at 120 days (12.66 and 14.05). The moderate values of genotypic and phenotypic coefficient of variation were recorded by the characters NMC at harvest (7.89 and 9.37), stalk height at 360 days (7.76 and 10.52), internodes/stalk at 360 days (7.63 and 9.44), cane yield (6.76 and 8.83), stalk weight at 360 days (6.49 and 8.54) and stalk diameter at 360 days (5.67 and 7.64).

The lowest values of genotypic and phenotypic coefficient of variation were reported for juice purity \% (1.42 and 2.06) and other quality parameters. Hapase and Hapase (1990) obtained highest GCV and PCV for germination per cent, total and millable height of cane, moderate for number of internodes and low for brix per cent and purity per cent. Also similar results were found by Doule and Balasundaram (1997) and Hapase and Repale (2004).

Table.1 Analysis of variance showing mean square for sixteen characters in sugarcane

\begin{tabular}{|l|c|c|c|c|c|c|c|}
\hline Source & d.f. & $\begin{array}{c}\text { Germination } \\
\text { \% at 45 days }\end{array}$ & $\begin{array}{c}\text { Tillers at } \\
\mathbf{1 2 0} \text { days } \\
\mathbf{( 0 0 0 / h a )}\end{array}$ & $\begin{array}{c}\text { Shoots at } \\
\mathbf{2 4 0} \text { days } \\
\mathbf{( 0 0 0 / h a )}\end{array}$ & $\begin{array}{c}\text { Stalk } \\
\text { height } \\
(\mathbf{c m}) \mathbf{a t} \\
\mathbf{3 6 0} \text { days }\end{array}$ & $\begin{array}{c}\text { Stalk } \\
\text { diameter } \\
\text { (cm) at } \\
\mathbf{3 6 0} \text { days }\end{array}$ & $\begin{array}{c}\text { Internodes } \\
\text { /stalk at } \\
\mathbf{3 6 0} \text { days }\end{array}$ \\
\hline Replication & 2 & 19.798 & 18.908 & 0.321 & 66.811 & 0.0002 & 0.784 \\
\hline Genotype & 29 & $175.318^{* *}$ & $\begin{array}{c}1648.577^{*} \\
*\end{array}$ & $\begin{array}{c}1298.588^{*} \\
*\end{array}$ & $\begin{array}{c}1515.27 * \\
*\end{array}$ & $0.0746^{* *}$ & $11.149^{* *}$ \\
\hline Error & 58 & 17.312 & 117.338 & 149.652 & 330.086 & 0.0159 & 1.666 \\
\hline S.Em \pm & & 2.402 & 6.254 & 7.062 & 10.489 & 0.072 & 0.745 \\
\hline C.V.\% & & 7.39 & 6.07 & 8.55 & 7.10 & 5.11 & 5.54 \\
\hline
\end{tabular}

\begin{tabular}{|l|c|c|c|c|c|c|}
\hline Source & d.f. & $\begin{array}{c}\text { Stalk weight } \\
(\mathbf{k g}) \text { at 360 } \\
\text { days }\end{array}$ & $\begin{array}{c}\text { NMC at } \\
\text { harvest } \\
(\mathbf{0 0 0 / h a})\end{array}$ & $\begin{array}{c}\text { Cane yield } \\
(\mathbf{t} / \mathbf{h a})\end{array}$ & $\begin{array}{c}\text { Juice brix } \\
\text { \% at 360 } \\
\text { days }\end{array}$ & $\begin{array}{c}\text { Sucrose \% } \\
\text { juice at 360 } \\
\text { days }\end{array}$ \\
\hline Replication & 2 & 0.007 & 1.905 & 8.358 & 0.591 & 1.228 \\
\hline Genotype & 29 & $0.019^{* *}$ & $272.861^{* *}$ & $238.684^{* *}$ & $2.273^{* *}$ & $1.834^{*}$ \\
\hline Error & 58 & 0.003 & 32.71 & 45.349 & 0.478 & 0.512 \\
\hline S.Em \pm & & 0.035 & 3.302 & 3.888 & 0.399 & 0.413 \\
\hline C.V.\% & & 5.38 & 5.04 & 5.67 & 3.19 & 3.57 \\
\hline
\end{tabular}

\begin{tabular}{|l|c|c|c|c|c|c|}
\hline Source & d.f. & $\begin{array}{c}\text { Juice purity \% } \\
\text { at 360 days }\end{array}$ & CCS \% & $\begin{array}{c}\text { Fibre \% } \\
\text { cane }\end{array}$ & $\begin{array}{c}\text { Pol \% } \\
\text { cane }\end{array}$ & CCS (t/ha) \\
\hline Replication & 2 & 4.895 & 0.848 & 0.065 & 0.621 & 0.422 \\
\hline Genotype & 29 & $7.119^{* *}$ & $0.996^{* *}$ & $0.449^{* *}$ & $0.995^{* *}$ & $6.185^{* *}$ \\
\hline Error & 58 & 1.881 & 0.306 & 0.159 & 0.282 & 1.327 \\
\hline S.Em \pm & & 0.791 & 0.319 & 0.230 & 0.307 & 0.665 \\
\hline C.V. \% & & 1.48 & 3.90 & 2.66 & 3.53 & 6.85 \\
\hline
\end{tabular}


Table.2 General mean, phenotypic range, variance components, genotypic coefficient of variation (GCV), phenotypic coefficient of variation $(\mathrm{PCV})$, heritability and genetic advance (\% of mean) of sugarcane genotypes

\begin{tabular}{|c|c|c|c|c|c|c|c|c|c|}
\hline Characters/ Parameters & $\begin{array}{l}\text { General } \\
\text { Mean }\end{array}$ & $\begin{array}{c}\text { Range } \\
\text { (Phenotypic) }\end{array}$ & $\begin{array}{l}\text { Genotypic } \\
\text { variance }\end{array}$ & $\begin{array}{c}\text { Phenotypic } \\
\text { variance }\end{array}$ & $\begin{array}{c}\text { Environmental } \\
\text { variance }\end{array}$ & $\begin{array}{c}\text { GCV } \\
(\%)\end{array}$ & $\begin{array}{l}\text { PCV } \\
(\%)\end{array}$ & $\begin{array}{c}\mathbf{H}^{2}(\mathbf{b}) \\
(\%)\end{array}$ & $\begin{array}{c}\text { G.A. as } \\
\% \text { of } \\
\text { mean }\end{array}$ \\
\hline Germination $\%$ at 45 days & 56.27 & $44.52-72.87$ & 52.66 & 69.98 & 17.31 & 12.90 & 14.87 & 75.30 & 23.05 \\
\hline Tillers at 120 days $(000 / h a)$ & 178.35 & $139.60-227.25$ & 510.41 & 627.75 & 117.33 & 12.66 & 14.05 & 81.30 & 23.53 \\
\hline Shoots at 240 days $(000 / h a)$ & 143.03 & $112.05-211.89$ & 382.97 & 532.63 & 149.65 & 13.68 & 16.14 & 71.90 & 23.90 \\
\hline Stalk height $(\mathrm{cm})$ at 360 days & 255.88 & 209.33-297.00 & 395.06 & 725.15 & 330.08 & 7.76 & 10.52 & 54.50 & 11.81 \\
\hline Stalk diameter $(\mathrm{cm})$ at 360 days & 2.47 & $2.11-2.75$ & 0.02 & 0.035 & 0.016 & 5.67 & 7.64 & 55.20 & 8.68 \\
\hline Internodes /stalk at 360 days & 23.29 & $19.65-26.49$ & 3.16 & 4.82 & 1.66 & 7.63 & 9.44 & 65.50 & 12.73 \\
\hline Stalk weight (kg) at 360 days & 1.10 & $0.96-1.30$ & 0.0005 & 0.009 & 0.004 & 6.49 & 8.54 & 57.90 & 10.19 \\
\hline NMC at harvest $(000 / h a)$ & 113.38 & $101.67-142.88$ & 80.05 & 112.76 & 32.71 & 7.89 & 9.37 & 71.00 & 13.70 \\
\hline Cane yield (t/ha) & 118.72 & $100.59-131.82$ & 64.44 & 109.79 & 43.35 & 6.76 & 8.83 & 58.70 & 10.67 \\
\hline Juice brix $\%$ at 360 days & 21.65 & $20.08-23.41$ & 0.59 & 1.07 & 0.47 & 3.57 & 4.79 & 55.50 & 5.49 \\
\hline Sucrose \% juice at 360 days & 20.04 & $17.92-21.44$ & 0.44 & 0.95 & 0.51 & 3.31 & 4.87 & 46.30 & 4.64 \\
\hline Juice purity $\%$ at 360 days & 92.52 & $89.23-95.67$ & 1.74 & 3.62 & 1.88 & 1.42 & 2.06 & 48.10 & 2.04 \\
\hline $\operatorname{CCS} \%$ & 14.15 & $12.45-15.08$ & 0.23 & 0.53 & 0.30 & 3.38 & 5.17 & 42.90 & 4.57 \\
\hline Fibre \% cane & 14.98 & $14.03-15.58$ & 0.09 & 0.25 & 0.15 & 2.07 & 3.38 & 37.80 & 2.63 \\
\hline Pol \% cane & 15.03 & $13.61-16.17$ & 0.23 & 0.52 & 0.28 & 3.24 & 4.80 & 45.60 & 4.51 \\
\hline $\operatorname{CCS}(\mathrm{t} / \mathrm{ha})$ & 16.80 & $13.61-19.87$ & 1.62 & 2.94 & 1.32 & 7.57 & 10.22 & 55.00 & 11.57 \\
\hline
\end{tabular}


In present study, the highest heritability estimate $(81.30 \%)$ was obtained for tillers at 120 days followed by germination $\%$ at 45 days $(75.30 \%)$, shoots at 240 days $(71.90 \%)$, NMC at harvest $(71.00 \%)$ and internodes/stalk at 360 days $(65.50 \%)$. Low heritability was observed for fibre \% cane $(37.80 \%)$ followed by CCS \% at harvest $(42.90 \%)$. Heritability for rest of the characters was recorded moderate to low. Genetic advance as per cent of mean was recorded as high as 23.90 for shoots at 240 days followed by tillers at 120 days (23.53), germination $\%$ at 45 days (23.05), NMC at harvest (13.70), internodes/stalk at 360 days (12.73), stalk height at 360 days (11.81) and CCS (t/ha) (11.57); whereas, for rest of the characters genetic advance was moderate to low (Table 2).

Shift in the gene frequency towards superior side under selection pressure is termed as genetic advance and is generally expressed as percentage of mean (genetic gain). Johnson et al., (1955) found it more useful to estimate heritability values together with genetic advance in predicting the ultimate choice of the best genotypes by selection. However, high genetic gain along with high heritability showed most effective condition for selection.

High heritability coupled with high genetic advance was observed for the characters tillers at 120 days (000/ha) followed by germination $\%$ at 45 days, shoots at 240 days (000/ha), NMC at harvest (000/ha) and internodes/stalk at 360 days. This indicated that these characters are governed by additive gene action and selection for these characters will be useful in choice of best genotype. Hapse and Repale (2004) reported high heritability coupled with high genetic advance for number of tillers at 120 days, germination percentage, total height and millable height of cane. Kumar et al., (2004) observed same trend for number of tillers at 240 days, cane height and number of internodes/stalk. Similar results were obtained by Rahman et al., (2008), Rahman and Bhuiyan (2009), Kumar et al., (2010) and Pawar et al., (2011) for the traits like stalk height and other yield contributing characters.

From the above results and discussion it can be concluded that high heritability coupled with high genetic advance was observed for the characters tillers at 120 days (000/ha) followed by germination $\%$ at 45 days, shoots at 240 days (000/ha), NMC at harvest (000/ha) and internodes/stalk at 360 days. This indicated that these characters are governed by additive gene action and selection for these characters will be useful in choice of best genotype.

\section{Acknowledgements}

The authors wish to thank, Honorable Vice Chancellor, Directorate of Research \& Dean PG Studies, Registrar, Main Sugarcane Research Station, Library and Agricultural Statistics Departments of N.M. College of Agriculture, N.A.U., Navsari 396450 for providing necessary facilities during the course of studies and investigation.

\section{References}

Anbanandan, V., and Saravanan, K. 2010. Genetic variability in interspecific and intergeneric progenies in sugarcane. Plant Archives, 10 (2): 627-632.

Doule, R.B., and Balasundaram, N. 1997. Variability, heritability and genetic advance for yield and quality attributes in sugarcane. Indian Sugar, 47 (7): 499502.

Hapase, R. S., and Repale J.M. 2004. Variability studies of some quantitative and qualitative characters in sugarcane varieties. Indian Sugar, LIV (3): 205210. 
Hapase, R.S., and Hapase, D.G. 1990. Genetic variability studies in late maturing sugarcane varieties. Bhartiya Sugar, 15 (10): 13-16.

Johnson, H.W., Robinson, H.F. and Comstock, R.E. 1955. Genotypic and phenotypic correlation in soybeans and their implication in selection. Agron. J., 47: 477-483.

Kadian, S.P., Chander Kishor and Sabharval, P.S. 1997. Genetic variability and heritability in sugarcane. Indian Sugar, 46 (12): 937-975.

Khan, M.I., Chattergee, A. and Bargale, M. 1991. Genetic variability and character association analysis for yield and its attributes in sugarcane. Co-operative Sugar, 23 (1): 29-33.

Kumar, K., Singh, P.K. and Singh, J.R.P. 2004. Genetic variability and character association in sub-tropical clones of sugarcane (Saccharum complex hybrid). Indian Sugar, LIV (3): 189-198.

Kumar, N., Singh, T. and Kumar, V. 2010. A study on genetic parameters, repeatability and predictability in plant and ratoon crops of sugarcane (Saccharum officinarum L.). Indian Sugar, LX (2): 23-27.

Panse, V.G., and Sukhatme, P.V. 1978. "Statistical methods for Agricultural Workers". ICAR, New Delhi.

Patel, K.C., Patel, A.I.; Mali, S.C.; Patel, D.U. and Vashi R.D. 2006. Variability, correlation and path analysis in sugarcane (Saccharum spp.). Crop Res., 32 (2):213-218.

Pawar, D.S., Hapse, R.S.; Repale, J.M. and Deshmukh, R.B. 2011. Studies on genetic variability, heritability and genetic advance in different sugarcane genotypes. Proc. of $10^{\text {th }}$ Joint Conv. of STAI and DSTA. Pp: 206-215.

Rahman, M.M., and Bhuiyan, M.S.R. 2009. Variability, heritability and genetic advanced for cane yield and its components in some indigenous and exotic promising clones of sugarcane (Saccharum officinarum L.). Indian Sugar, LIX (2): 35-41.

Rahman, M.M., Podder, B.P.; Rahim, M.A. and Karim, K.M.R. 2008. Estimates of genotypic and phenotypic variation, heritability and genetic advance under some characters of sugarcane clones. Indian Sugar, LVIII (4): 31-36.

Tyagi, S.D., and Singh, D.N. 1998. Studies on genetic variability for stalk characters in sugarcane. Indian Sugar XL VIII: 259262.

Tyagi, V.K., Sharma, S. and Bhardwaj, S.B. 2011. A study on the nature and magnitude of variations in different traits in sugarcane. Electronic J. Plant Breeding, 2(3):334- 341.

Verma, P.S., Pal, S, and Karma, N.K. 1999. Genetic variability and correlation studies in sugarcane. Indian Sugar, 49 (2): $125-128$.

\section{How to cite this article:}

Patil, P.P. and Patel, D.U. 2017. Study of Genetic Variability and Heritability in Sugarcane (Saccharum spp. Complex). Int.J.Curr.Microbiol.App.Sci. 6(9): 3112-3117. doi: https://doi.org/10.20546/ijcmas.2017.609.384 